\title{
THE IMPORTANCE OF INTERACTIVE LEARNING MEDIA IN A NEW CIVILIZATION ERA
}

\author{
K., Kustyarini ${ }^{i}$, \\ Sri Utami, \\ Endang Koesmijati \\ Wisnuwardhana University Malang, \\ Indonesia
}

\begin{abstract}
:
The Covid-19 pandemic has left the people down to earth. Such conditions are not immediately forgotten and are avoided from the construction of thoughts in the world of education today. Learning from/at Home (BDR) is the latest solution to keep the spread of COVID-19 from becoming more widespread and avoiding the disease. In the era of a new civilization in our world of education, it is very necessary to package a new learning model. Meanwhile, learning Indonesian in the 2013 curriculum uses a text-based approach. This text-based learning trains individuals to solve the problems they face and think critically according to what is in real life. The development model used in this study is the APPED Model. This model can be used as a reference in R\&D (Research and Development) research. The main objective of this research is the importance of the process of developing interactive multimedia models for learning media in new civilizations. The discussion of this research is the steps and process of using interactive multimedia with the right use as a massage medium that will stimulate thinking, thereby encouraging the process of student learning to be more concrete. The stages of implementing interactive multimedia in learning are Introduction (Program Introduction) including Title Page, Learning Prompt or guide, Presentation Objectivity, Instructions, Knowledge Priority Stimulation (apperception in the form of knowledge stimulation), Initial Control; Presentation of Information includes presentation mode or presentation mode, length of presentation text, graphics and animation, color and usage; Question of Response (Question and responses) and Judging of Response (Assessment of responses). So interactive multimedia learning is important to be applied to the new civilization era by utilizing technology.
\end{abstract}

Keywords: importance, interactive learning, media, new civilization era

i Correspondence: email kustyarinireinanda@yahoo.com 


\section{Introduction}

This pandemic urges testing of distance education almost which has never been carried out simultaneously before for all elements of education, namely students, teachers to parents. Given that during a pandemic, time, location, and distance are currently big problems (Kusuma, 2020). So that distance learning becomes a solution to overcome difficulties in implementing face-to-face learning. The use of multimedia as teacher creativity and support distance learning efforts. One of them is the use of interactive learning media as an effort to develop distance learning. One of the objectives of learning with interactive multimedia is to replace and/or complement and support the elements: objectives, materials, methods, and assessment tools that exist in the teaching and learning process in conventional education systems that we usually do.

This presents a challenge to all elements and levels of education to keep classrooms active even though schools have closed. Government learning at/from home programs require the readiness of educators and students to interact or learn online. Studying at home has been criticized and has shown low learning outcomes. One of the causes of low learning outcomes, especially in online conditions during this pandemic, is the lack of interactive multimedia-based learning. Information technology can be used to develop learning models, especially online learning (Asbari, 2002). Remote areas also face major obstacles, one of which is the limited human resources in the use of technology. Victims of the COVID-19 outbreak, not only education at the elementary school / Madrasah Ibtidaiyah, junior high school / Madrasah Stanawiyah, and senior high school / Madrasah Aliyah, but also universities. All levels of education from elementary to tertiary institutions (universities) both under the Ministry of Education and Culture of the Republic of Indonesia and those under the Ministry of Religion of the Republic of Indonesia all have a negative impact because students are "forced" to study from home because of face-to-face learning. eliminated to prevent the transmission of COVID-19. Even though not all students, students and students are used to learning through Online. Moreover, many teachers and lecturers are still not proficient in teaching using internet technology or social media, especially in various regions.

The development of multimedia technology has great potential in changing the way a person learns, obtains information, adapts information, and so on. Multimedia also provides opportunities for educators to develop learning techniques to produce maximum results. The current condition is urgent to make innovations and adaptations related to the use of available technology to support the learning process (Prasasti, 2020). Its practice requires educators as well as students or students to interact and transfer knowledge online. Online learning can take advantage of platforms in the form of applications, websites, social networks, and learning management systems (Gunawan et al., 2020). Technology in online learning and learning will benefit all parties and support student learning goals. These platforms can be used to support knowledge transfer supported by various discussion techniques and others.

The role of the teacher as an educator is to instill the basic values of character development of students in life, including in the wise use of advances in information 
technology and as an inspiration for students (Effendy, 2012) Even though information technology develops so fast and learning resources are easy to obtain. however, the role of teachers as educators cannot be replaced by technological advances, and this can be realized if teachers do not stop learning and developing themselves. In the learning process, the teacher must build interactions that can meet the psychological needs of students. A teacher must be able to make students feel able and give appreciation for their learning outcomes. One of them is using interactive multimedia learning in the application of online learning.

Interactive multimedia is a media that is equipped with a controller that can be operated by the user and the user can also choose what he wants for the next process. Interactive multimedia aims to present information in a form that is fun, interesting, easy to understand, and clear. Information will be easy to understand because as many senses as possible, especially the ears and eyes are used to absorb the information. This research is very important in an overview effort related to online learning in an outbreak. The resulting media will facilitate the teaching and learning process. This can happen because the resulting interactive media is teaching material using interactive media. All components needed in learning are contained in the media. With the use of interactive multimedia in learning activities, students or students become active. The importance of using interactive multimedia in learning conditions in the new civilization.

\section{Literature Review}

\subsection{Multimedia}

The term multimedia has a broad impact on human life. Along with the development of information and communication technology that is so fast, the term multimedia is increasingly popular. The term does not only refer to topics, materials, subjects in schools, and courses in tertiary institutions but more than that it also refers to expertise, profession and even refers to the tools to play the program. Therefore, it cannot be denied that the terminus is widely used in society. The term multimedia set nomologically comes from the words multi and media. Multi-meaning multiplier or and media means the means to convey messages or information such as text, images, sound, video. So, in linguistic terms, the term multimedia is a combination of many or several media such as text, images, sound, the video that are used to convey messages or information. This understanding is still very general, that is, it does not specifically indicate how it is shaped and how the manufacturing process is and it is not implied; whether it is manipulated digitally or manually.

Multimedia is the use of computers to create and combine text, graphics, audio, moving images (animated videos) by combining links and tools that allow users to navigate, interact, create and communicate (Suyanto, 2003: 21-21). The combination of computer and video or multimedia is generally a combination of three elements, namely sound, images, and text or multimedia is a combination of at least two input-output media of data, this media can be audio (sound, music), animation, video, graphic text and images (Turban, 2002) or multimedia is a tool that can create dynamic and interactive 
presentations that combine text, graphics, animation, audio, and video images. Multimedia in this chapter is an important study material because we will discuss everything from understanding, components, distribution, authoring tools, and the use of multimedia. This discussion is expected to provide a conceptual understanding that becomes the basis for the main discussion of this book, namely multimedia learning. Although discussed conceptually, we will present a concrete example to make it easier to understand.

One way to increase motivation in using multimedia is by providing activities. Therefore, multimedia learning must be interactive, to provide opportunities for students to move. We recommend that interactive learning multimedia be given various kinds of interactivity, for example page navigation, menu/button / link controls, animation controls, hypermaps, feedback, drag \& drop, simulation controls, game controls, and others. The advantages of multimedia include: easy to use, intuitive interface, immersive experience, self-paced interaction, long retention, a better understanding of content, costeffectiveness, more fun.

\subsection{Utilization of Multimedia}

Currently, the use of multimedia is not only for the field of learning or education, but also for other fields in our lives, for example, business, industry, tourism, and entertainment. In the field of business and industry, multimedia is the foundation in optimizing the promotion of products and services through advertising, company profiles, presentations, training, product demos, online catalogs, simulations, marketing, communication between branches, and others. In the field of tourism and entertainment, multimedia has an equally important role. Information on tourism objects can be packaged into multimedia that is displayed on the website or on public computer terminals that are often found in hotels, airports, malls, museums, restaurants, and others. The world of entertainment is also dominated by multimedia, for example in the form of games, animation films, 3D films, performing arts, and others. Various sectors that take advantage of multimedia include (1) Education. The use of multimedia in education can be in the form of multimedia interactive learning (MP1), e-learning, learning CDs, tutorial CDs. (2) Business. The use of multimedia in the business field can be in the form of profiles, product demos, advertising, e-commerce, e-training. (3) Tourism. The use of multimedia in tourism can be in the form of Tourist maps, travel, performing arts. (4) Entertainment. The use of multimedia in the entertainment sector can be in the form of games, animated films. (5) Household. The use of multimedia in the household can be in the form of CD cooking, gardening, gymnastics, skills.

Multimedia is made for specific purposes depending on its use. Multimedia that is used to make it easier for students to understand learning material to achieve certain learning objectives is often referred to as learning multimedia. In using multimedia applications, students certainly carry out activities or interact with it, for example by clicking on the navigation buttons (next, back, home), clicking the menu, choosing alternative answers, writing text, shifting objects, and so on. Such multimedia applications are commonly referred to as interactive learning multimedia. 
The use of interactive learning media is used by teachers' aims so that students can learn actively. Interactive media based on the use of technology will greatly support the learning process because technology is an approach from a hardware point of view that aims at the media for implementing the educational process through the utilization of teaching tools such as teaching machines, language laboratories, program teaching, closed-circuit television, films, slides, simulators, overheads, videotape recorders. There are 3 types of use of multimedia learning, namely: (1) Multimedia is used as an element of classroom learning. For example, if the teacher explains a material through classroom teaching or based on a reference book, multimedia is used as a complementary medium to explain the material taught in front of the class. Exercises and tests in this first type are not provided in a multimedia package but the print form provided by the teacher. (2) Multimedia is used as independent learning material. In this second type, multimedia may or may not support classroom learning. Unlike the first type, in the second type, all instructional needs of the user are met entirely in the multimedia package. This means that all facilities for learning, including exercises, feedback, and tests that support learning objectives are provided in the package. (3) Multimedia is used as the only medium in learning. Thus, all learning facilities that support learning objectives have also been provided in this package.

\subsection{Interactive Multimedia Model}

The interactive multimedia learning model can improve the mastery of concepts for teachers and lecturers. Besides, it is also supported by the results of research by Sriyanti (2012) which utilizes multimedia in the Blended e Learning Model to also be able to student learning outcomes. Other studies also show that the development of interactive multimedia learning can improve students' mastery of concepts (Gunawan, et al, 2014). An interactive multimedia is a tool that is equipped with a control device that can be operated by the user in selecting something they want. Examples of interactive multimedia are inter-active learning multimedia (interactive multimedia-based learning), game applications, and others.

In general, multimedia learning is very useful in the teaching and learning process. The use of multimedia learning can make learning more interesting, more interactive, increased learning motivation, and more focused and increased attention to learning. One of the objectives of learning with interactive multimedia is to replace and/or complement and support the elements: objectives, materials, methods, and assessment tools that exist in the teaching and learning process in conventional educational systems that we usually do. According to Nandi (2006), there are several formats of Interactive multimedia-based learning offerings such as the following:

1) The tutorial model is one of the interactive learning models used in the teaching and learning process using the software in the form of a computer program containing course material. Tutorials in interactive multimedia programs are intended as a substitute for humans as instructors. The stages of using the tutorial model are as follows.

a. The computer presents the material, 
b. Students respond to the material,

c. Student responses are evaluated automatically with the student taking the next question.

d. Repeating or continuing the next stage.

2) The Drills Model is a computer-based interactive learning model (CBI) which aims to provide a more concrete learning experience through the provision of question exercises to test student performance through the speed of solving the questions given by the program. The stages of the drill model material are as follows.

a. Presentation of the problem in the form of practice questions at a certain level based on the topic,

b. Record and evaluate the program,

c. Feedback,

d. If the resulting answer is correct then the next question will be presented, but if it is wrong there is a repetition of the exercise at the end of the whole question.

3) The simulation model is a learning strategy that aims to provide a real experience through the creation of an imitation of a form of experience that is closer to the actual atmosphere and takes place in an atmosphere without risk. The simulation model is divided into four categories, namely: physical, situation, procedure, and process. In general, the stages of the simulation model material are as follows: introduction, presentation, information, (simulation 1, simulation 2, etc.), question and answer responses, response assessment, giving feedback on responses, repetition, teaching setting segments, and closing.

4) The Instructional Games Model is a learning model using computer-based interactive multimedia. The purpose of the Instructional Games Model is to provide an atmosphere or environment that provides learning facilities that enhance students' abilities. This instructional game model does not need to imitate real things but has a certain character for students. The Instructional Games model is to provide an atmosphere or environment that provides learning facilities that increase student abilities. This instructional game model does not need to imitate real things but has a certain character for students. An example is a quiz, the existing meter.

\subsection{Principles of Interactive Learning Media}

Learning media can trigger efforts to change the existing learning system. Learning media has several advantages for its users, including (1) teaching will attract more attention so that it can foster motivation (2) learning media helps provide learning experiences that are difficult to obtain in other ways (3) learning methods will be more varied, not solely verbal communication through speech, so that it is not boring and (4) doing more learning activities because not only listen to descriptions, but also other activities such as observing, doing, and demonstrating (Latuheru, 1998: 22).

According to Vaughan (2011), there are three types of multimedia, namely interactive multimedia, hyperactive multimedia, linear multimedia, and multimedia. 
Meanwhile, according to Sigit (2008), multimedia is divided into two categories, namely: linear multimedia and interactive multimedia. An interactive multimedia is a tool that is equipped with a control device that can be operated by the user in selecting something they want. Examples of interactive multimedia are inter-active learning multimedia (interactive multimedia-based learning), game applications, and others. Several principles need to be applied when we are going to accommodate multimedia for learning so that students can learn more optimally. Also, the application of the principle of interactivity in multimedia learning includes quizzes, drag-and-drop activities, simulations, games, and others.

The principles and objectives of learning organized with interactive media are to be able to capture/receive, process, store, and release the information that has been processed. Media that can accommodate these requirements is a computer. Computers can present information in the form of video, audio, text, graphics, and animation (simulation). For example, in mathematics learning, some topics that are difficult to convey conventionally or require high accuracy can be implemented with the help of computer/multimedia technology, such as graphics and diagrams that can be presented easily and quickly, image display, color, visualization, video, animation can optimize the role of the senses in receiving information into the information system (Kariadinata, 2010). Multimedia-based learning with the help of computers that are owned by everyone, namely android. Utilization of this technology can benefit and hone critical thinking from teachers. Tools that are easy to find and even everyone has them, control tools that online learning can use.

\section{Method}

\subsection{Development of Interactive Learning Media}

The development model used in this study is the APPED Model. This model can be used as a reference in $R \& D$ (Research and Development) research. The essence of research in this type of $R \& D$ is an element of research and development. The steps are undertaken in this APPED model to follow the logic of this type of R\&D research. The explanation is as follows.

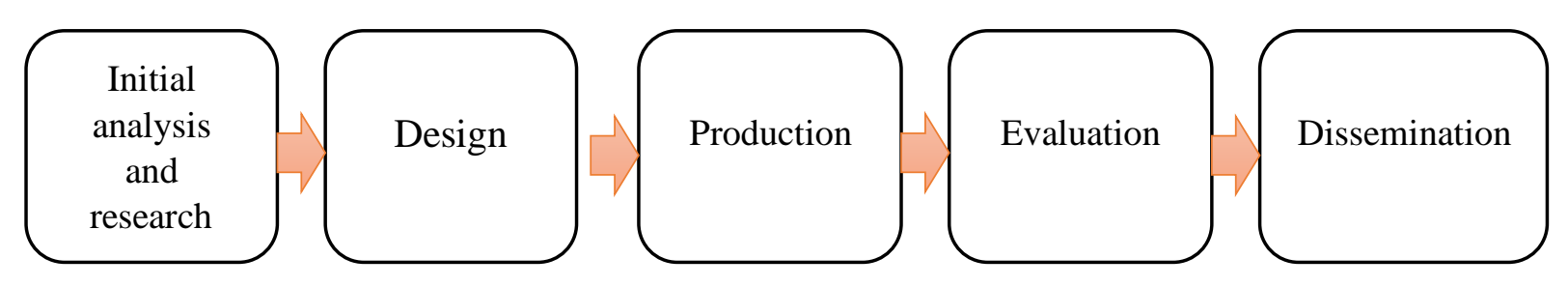

\subsection{The APPED Model Step}

The steps in this APPED model are as follows: 


\section{A. Initial Analysis and Research}

In this first step, we undertake a needs analysis and initial research. The output of this step is a description of the MPI to be developed. The results of this step will then be used as the basis for designing the MPI. Requirements analysis is a systematic process of determining the goal or target of the desired conditions in the presence of MPI, then analyzing how much the gap is between the target and the current condition, and finally determining the priority of the required solutions. Data can be obtained through various means such as questionnaires, interviews, documentation, observation, FGD, and others. Next, we conduct initial research to obtain more detailed information about the MPI needed. Some of the steps in this initial research are student characteristic analysis, technology analysis, material coverage analysis, learning achievement analysis and task analysis, existing MPI analysis, literature study, cost needs analysis.

\section{B. Design}

In this step, we do instructional design, flowchart creation, screen design, and storyboard creation. The output of this step is design documentation which contains an outline, flowchart, screen design, and storyboard. This document will be used as a guide to produce MPI. From the results of the task analysis in the first stage, we can design an outline of the material and the sequence of each material according to the analysis of learning outcomes. The material outline can be realized in the form of a multimedia content outline table (GBIPM) which contains material topics, multimedia components used, time duration, learning resources, and others. After that, we make the overall material framework in the form of a flowchart so that we can see the overall relationship of the material from MPI. The standard symbol used to make a flowchart can be seen in the image below.

Table 1: Image Symbols, Names and Functions

\begin{tabular}{|c|c|c|}
\hline Symbol & Name & Function \\
\hline & Terminator & Program start / end \\
\hline & Flow Line & Program flow direction \\
\hline & Preparation & $\begin{array}{c}\text { Initialization / } \\
\text { initial pricing process }\end{array}$ \\
\hline & Process & $\begin{array}{l}\text { Process calculation / } \\
\text { data processing }\end{array}$ \\
\hline & $\begin{array}{l}\text { Data Input / } \\
\text { Output }\end{array}$ & $\begin{array}{c}\text { Process input / output data, } \\
\text { parameters, information }\end{array}$ \\
\hline & $\begin{array}{l}\text { Predefined Process } \\
\text { (Sub Program) }\end{array}$ & $\begin{array}{l}\text { The start of a sub program / } \\
\text { process to run a sub program }\end{array}$ \\
\hline & Decision & $\begin{array}{c}\text { Comparison of statements, } \\
\text { selecting data that provides } \\
\text { options for next steps }\end{array}$ \\
\hline
\end{tabular}




\section{Discussion}

It cannot be denied that multimedia technology can make a big impression in the field of communication and education because it can integrate text, graphics, animation, audio, and video. These models can be used in classroom learning or learning alone. Can also be used for learning at home and school. Learning sessions can be adjusted according to the stage of acceptance and understanding of students. Student achievement and success will be tested. If the student does not reach a satisfactory stage, a recovery session will also be held. Student achievement records will be kept so that student achievement can be monitored. The learning concept itself can be implemented if the information is interesting and motivates students to continue learning. This can be achieved if the material or information is well designed using multimedia.

The application of new technology, organizational engineering, and skills development can be a reflection of teacher performance which in an individual context illustrates individual creativity in carrying out individual roles as well as creative teachers. Interactive multimedia is one of the media for implementing learning that teachers can use as a tool for the learning process in times like this.

Interactive multimedia is a combination of various media in the form of text, images, graphics, sound, animation, video, interaction, etc. Which has been packaged into a digital file, used to convey messages based on the above definitions, it can be concluded that interactive multimedia is a multimedia display using a computer that integrates several kinds of media where users can learn interactively because it is equipped with a controller that functions as a liaison with the program so that users can choose what they want.

In the interactive learning process, there are several forms of communication, namely one way (one-way communication) and two ways (two ways communication), and many ways (multi ways communication) takes place between teachers and students. Teachers deliver learning materials and students respond (responses) to these materials. Interactive learning is an effective way to stimulate students to always want to learn. In this learning process, students are required to be active and are required to respond/respond to the material that has been delivered by the teacher. The media used can respond to students to interact with each other. This facilitates human resources in learning and learning objectives. Also, the implementation of multimedia learning requires tools that all levels of society have in modern times like this.

The implementation of learning using interactive multimedia requires assistive tools in the form of a laptop, LCD, projector, and speakers to support learning. The use of interactive learning media is used by teachers' aims so that students can learn actively. The stages of implementing interactive multimedia in learning are as follows:

1) Introduction (Program Introduction)
a. Program Title (Title Page)
b. Learning Prompt or guide
c. Objectivity of Presentation
d. Instructions 


\section{e. Knowledge Priority Stimulation (apperception in the form of knowledge stimulation) \\ f. Control Initials}

\section{2) Presentation of Information (Presentation of Information)}
a. Presentation mode or presentation mode
b. Length of presentation text
c. Graphics and animation
d. Color and use

\section{3) Question of Response (Question and responses) \\ 4) Judging of Response}

The steps and process of using the right interactive multimedia with proper use as a massage medium that will stimulate students' thoughts, feelings, concerns, and desires to encourage the student's learning process to be more concrete. Teachers must have critical thinking skills to carry out various analyzes, assessments, evaluations, reconstruction, decision making that lead to rational and logical actions (King, et al., 2010). Creativity, that is, a teacher must be able to find new things that haven't been there before that are original (Leen, et al., 2014). Communicative, that is, the teacher must be able to express new thoughts, ideas, knowledge, or information, both in writing and orally. Collaborative, namely a teacher must be able to work together effectively and show respect for team members to achieve common goals (Greenstein, 2012). Also, in the learning process, the teacher must build interactions that can meet the psychological needs of students. A teacher must be able to make students feel able and give appreciation for their learning outcomes. Especially in a new civilization like this with the plague.

Interactive media is used to make it easier for students to understand learning material to achieve learning objectives. In using interactive media applications, students certainly carry out activities or interact by clicking navigation buttons (next, back, home), clicking menus, choosing alternative answers, writing text, shifting objects, and others. One way to increase motivation in using interactive media is by providing activities. Therefore, multimedia learning must be interactive, to provide opportunities for students to move. Technological advances that encourage interactive media are important due to their dynamic use. The use of interactive media applications makes it easier for students to learn and understand the material. The use of interactive media applications also makes it easier for teachers to achieve learning goals.

\section{Conclusion}

Students or university students feel the impact on the teaching and learning process at/from home due to the obstacles they are going through. Less supportive facilities or infrastructure affect teaching and learning at/from home. The obstacle faced by teachers is the lack of knowledge of human resources in utilizing technology in getting the correct learning model from home. This greatly affects everything that is done in distance learning. An effort that can be developed by creative and critical teachers in a pandemic and a new civilization is the use of interactive multimedia. The use of interactive media 
can be used as an approach to student learning in new civilizations. Technology-based media will be beneficial for the development of learning at/from home by the Indonesian government. Implementation of the educational process through the use of appropriate teaching tools such as laptops, learning programs, appropriate technology media. This must be carried out with the right stages and processes.

The importance of implementing interactive learning media is that it affects learning objectives. The steps taken are easy to do and make it easier for teachers and right on target. The steps and process of using the right interactive multimedia with proper use as a massage medium that will stimulate students' thoughts, feelings, concerns, and desires to encourage the student's learning process to be more concrete. The use of interactive learning media is used by teachers' aims so that students can learn actively. The stages of implementing interactive multimedia in learning are Introduction (Program Introduction) including the Program Title (Title Page), Learning Prompt or guide, Presentation Objectivity, Instructions, Knowledge Priority Stimulation (apperception in the form of knowledge stimulation), Initial Control; Presentation of Information includes presentation mode or presentation mode, length of presentation text, graphics and animation, color and usage; Question of Response (Question and responses) and Judging of Response (Assessment of responses). This is what makes multimedia learning media important to do and apply.

\section{Recommendation}

This text-based learning trains individuals to solve the problems they face and think critically according to what is in real life. The development model used in this research is the APPED Model. This model can be used as a reference in R\&D (Research and Development) research.

\section{Conflict of interest}

The authors declare no conflicts of interest.

\section{Acknowledgement}

This research was funded by Directorate of Research and Community Service, Unemployment Research Scheme of Higher Education, Indonesian Ministry of Research, Technology and Higher Education.

\section{About the Author(s)}

K. Kustyarini is a Doctor of Education at the Wisnuwardhana University MalangIndonesia. 


\section{References}

Ahmed, S., Shehata, M., \& Hassanien, M. 2020. Emerging Faculty Needs for Enhancing Student Engagement on a Virtual Platform. MedEdPublish, 1-5. https://doi.org/https://doi.org/10.15694/mep .2020.000075.1

Asbari, M., Wijayanti, L. M., Hyun, C. C., Purwanto, A., Santoso. 2020. Effect of Tacit and Explicit Knowledge Sharing on Teacher Innovation Capability, Dinamika Pendidikan Vol. 14 No 1 tahun 2020.

Djamarah, S. B. \& A. Z. 2010. Strategi Belajar Mengajar. Jakarta: Rineka Cipta.

Gunawan, Suranti, N. M. Y., \& Fathoroni. 2020. Variations of Models and Learning Platforms for Prospective Teachers During the COVID-19 Pandemic Period. Indonesian Journal of Teacher Education, 1(2), 61-70.

Jessika Michaela Mintorogo, Ahmad Adib, A. W. S. 2014. Perancangan Media Interaktif Pengenalan Alphabet Berbasis Alat Permainan Edukatif Untuk Anak Usia Dini. Jurnal DKV Adi Warna.

Khasanah, D. R. A. U., Pramudibyanto, H., \& Widuroyekti, B. 2020. Pendidikan Dalam Masa Pandemi Covid-19. Jurnal Sinestesia, 10(1), 41-48.

Kusumaningsih, Rudy Pramono. 2020. Pengaruh media pembelajaran interaktif pada siswa MtS : Jurnal Manajemen Pendidikan Islam. Vol. 04 No. 01 (2020).

Munir, 2005, Konsep dan Aplikasi Program Pembelajaran Berbasis Komputer (Computer Based Interaction). UPI: P3MP.

Nandi. 2006. Penggunaan Multimedia Interaktif dalam Pembelajaran Geografi di Persekolahan. Jurnal “GEA" Jurusan Pendidikan Geografi Vol. 6, No.1.

Prastika, L. R., dkk. 2015. Pengaruh Penggunaan Multimedia Interaktif Berbasis Komputer Model Instructional Games terhadap Peningkatan Prestasi Belajar Siswa pada Mata Pelajaran Fisika. Prosiding Simposium Nasional Inovasi Pembelajaran dan Sains 2011 (SNIPS 2015) Bandung, (2015): hlm 397-400.

Rusman. 2005. Model-model Multimedia Interaktif Berbasis Komputer. UPI: P3MP.

Sadiman, Dkk. 2008. Media Pendidikan. Jakarta: Rajawali Pers.

Suyanto, M. 2003. Multimedia Alat Untuk Meningkatkan Keunggulan Bersaing. Yogyakarta: Andi Offset.

Turban, Dkk. 2002. Aplikasi Multimedia Interaktif. Yogyakarta: Gaung Persada.

Verawardina, U., Asnur, L., Lubis, A. L., \& Hendriyani, Y. 2020. Reviewing Online Learning Facing the Covid-19 Outbreak. 12(3), 385-392. 
Creative Commons licensing terms

Authors will retain the copyright of their published articles agreeing that a Creative Commons Attribution 4.0 International License (CC BY 4.0) terms will be applied to their work. Under the terms of this license, no permission is required from the author(s) or publisher for members of the community to copy, distribute, transmit or adapt the article content, providing a proper, prominent and unambiguous attribution to the authors in a manner that makes clear that the materials are being reused under permission of a Creative Commons License. Views, opinions and conclusions expressed in this research article are views, opinions and conclusions of the author(s). Open Access Publishing Group and European Journal of Open Education and E-learning Studies shall not be responsible or answerable for any loss, damage or liability caused in relation to/arising out of conflict of interests, copyright violations and inappropriate or inaccurate use of any kind content related or integrated on the research work. All the published works are meeting the Open Access Publishing requirements and can be freely accessed, shared, modified, distributed and used in educational, commercial and non-commercial purposes under a Creative Commons Attribution 4.0 International License (CC BY 4.0). 